\title{
The tragedy of remarriage in the Golden Age of television
}

\author{
Margaret Kohn
}

Joshua Dienstag's "Letter to M. Cavell" makes two arguments. It urges us to reconsider the claim that film is the source of insight into moral complexity and a fertile ground for fostering democratic sensibilities. The essay also shows that film can indeed illuminate the human condition, but it does so when it exposes the tension between eros and social structure, not when it suggests that this tension can be easily overcome. It is tempting to say that film can be democratic as long as it has the disruptive effect of atonal music rather than the soporific effect of jazz, but Dienstag does not take this position. Inspired by Rousseau's Letter to M. d'Alembert on the Theatre (Lettre à M. d'Alembert sur les spectacles), Dienstag does not comfort and flatter his reader by affirming the view that democratic communities are strengthened when the right kind of people appreciate the right kind of movies. There is no satisfying reconciliation of critique and community, which, quite appropriately, makes his essay more like The Rule(s) of the Game than The Philadelphia Story.

In this response, I will make a qualified case for the opposite view and suggest that films and even television shows can be texts that encourage reflexivity about moral paradox, political obligation and community. I will do this through a reading of a more recent work in the genre of "the tragedy of remarriage": the television show The Americans. The Americans is a commercially successful spy drama set in Washington, DC in the early 1980s. It incorporates aspects of high and low culture. It combines the elaborate atmospherics of Mad Men with elements of the spy genre, but at its core it is a story about marriage and, to a 
lesser degree, about politics. First, I will briefly review the key theoretical issues addressed in this collection: whether and how we can learn from film. Next, I will clarify how The Americans resembles the other remarriage films and can illuminate the issues they raise. Finally, I will explain what insights we can draw from the show and whether these insights could fortify democracy.

In addition to the very explicit debt to Rousseau, "The tragedy of remarriage: letter to $\mathrm{M}$. Cavell about cinema (a remake)" also bears the trace of another influence: Adorno. According to Dienstag, The Philadelphia Story, a commercially successful Hollywood film, is also a deeply ideological one. Dexter and Tracy's remarriage reaffirms the possibility of reconciling freedom and social order, eros and nomos. Its popularity was at least partially due to the appeal of this message. It also affirmed the American fantasy of a hierarchical yet egalitarian society. In The Philadelphia Story, after a brief period of misunderstanding, members of different social classes treat each other with affection and respect, while still ultimately choosing to remain within their own class. Renoir's The Rules of the Game provides neither the hope of psychic nor social reconciliation, and it is not surprising that it was reviled by audiences. The lesson here is that cinema can be critical, but it cannot be both critical and popular. This is one of the reasons why Dienstag concludes that it is not suited to the idealized role of instructing democratic sensibilities. Dienstag's essay raises three related questions: Can film inspire critical reflection on ethics and politics? If so, can these films be popular? And, if they are popular and critical, is there still something about the isolating experience of viewing a spectacle that undermines more appropriate forms of sociability?

The Americans unsettles the opposition between popular/ideological and critical/unpopular film. Initially, it might seem to be an odd example to draw on because it is not a film, nor does it obviously fall into the genre 
of a "comedy of remarriage." It is, however, a "filmlike" television show and one in which remarriage plays an important part. Attending to the theme of remarriage helps illuminate the central themes of the show. Is the difference between film and television a matter of degree or of kind? The distinction between television and film is introduced in Dienstag's essay in the context of a discussion about temporality. Television is associated with the temporality of the present: live television, reality television, and the simulacra of the live studio audience. He concedes, however, that the difference is not absolute. Films are often viewed on television, and television shows can have "filmlike" qualities. I will leave aside for now the important issue of the difference between viewing a show in the movie theater as opposed to viewing it at home. Dienstag does not explain what he means by "filmlike," but the concept makes intuitive sense and I assume that it describes shows that are designed to command sustained attention and ones that reward such sustained attention. The Americans is filmlike in the sense that its visual design, sound design, and plotting all remove it from the temporality of the present and draw the audience into a distinctive world, a world that demands and rewards close attention.

The Americans follows Philip and Elizabeth Jennings, two KGB agents who have lived most of their adult lives undercover as a married couple in the United States. They share a bed and have raised two children together (the oldest is a young teenager), but, while they are more than partners, they are not really a romantic couple. Elizabeth has a lover and admits to Philip that "it [marital love] never really happened for me." Midway during the first season, they separate and Philip moves into his own apartment, but, after a mission goes wrong and Elizabeth is shot and almost killed, she briefly wakes up and speaks to Philip in Russian for the first time. She says "come home." This is the remarriage.

How does this remarriage compare with the classic genre? Dienstag's essay juxtaposes two very different kinds of remarriage. Christine's return to her husband is not a renewal of love but a sign of defeat. Love unconstrained by social rules proves impossible and her return to her husband follows from her reluctant acceptance of this fact. Tracy Lord's remarriage to Dexter is precisely the inverse. Tracy recognizes 
that neither pure convention (George) nor pure rebellion (Mike) is the foundation for a satisfying marriage; it is possible and necessary to overcome this opposition in order to create something that preserves and transcends them both. The remarriage in The Americans is based on neither resignation nor reconciliation, but points to a third possibility.

At first, it might seem unlikely that we could draw lessons about marriage or moral perfectionism from The Americans, a show in which beautiful super-spies don disguises, fight villains, seduce informants and then return to their normal suburban home to nag their kids about homework and screen time. The premise seems so pulpy that I am sometimes embarrassed to publicly profess my love for the show. The Americans differs from the other remarriage films not only because it draws on the spy genre, but also because family plays a central role. Romantic love and parental love are equally important. Elizabeth's dilemma differs in some other key respects from Tracy's and Christine's. Elizabeth is not torn between three different romantic suitors and the options that she considers represent different ways of living. This is due in part to the moral complexity that is explored in the show. The characters in The Americans confront what Cavell calls "moral paradox" and they also wrestle with the tension between obligation and desire. These conflicts, which begin as binaries, become increasingly enmeshed in more complicated webs. The conflict between duty and desire is a familiar one, but increasingly we see how duties conflict with other duties and desires conflict with other desires.

In the first episode of the show, a top KGB officer plans to defect to the United States and Philip and Elizabeth are ordered to prevent this by kidnapping him and exfiltrating him back to Russia. Philip, whose easygoing demeanor has made him feel at home in the United States, tentatively suggests that maybe they should defect too. He enjoys the abundance of American life and his enjoyment has weakened his commitment to Soviet ideology. The dilemma he faces is not between duty and desire, but between two desires, his love for Elizabeth, who seems unwavering in her ideological commitments, and his desire to be free from his responsibilities to Mother Russia. 
The show eventually introduces at least six different factors that motivate the central characters: romantic desire, familial love, masculinity, honor, duty and political ideology. I use the term "duty" in the Kantian sense of a universal moral law that prohibits certain conduct regardless of the possible beneficial consequences. These concerns become increasingly important in Season Two when Philip has to kill innocent people in order to ensure the success of a mission that aims to expose US support for paramilitary organizations and the use of torture in Central America. They teach their children never to lie while literally living a lie. "Honor" is the term I use to describe the norms that Hegel grouped under sittlichkeit (ethical life), including professional identity and social roles. It is a way of describing the tension that characters experience when their professional obligations conflict with other duties or desires. This tension is explored most clearly through the character of FBI agent Stan Beeman, a skilled agent who eventually faces a choice between his professional obligations and his love for Nina, his informant.

In the two films that Dienstag analyzes, the female protagonists are torn between three romantic possibilities which correspond to different sides of themselves and different positions in the social order. Initially, Elizabeth's affair with Gregory would seem an obvious parallel. $\mathrm{He}$ is a radical black activist, who shares her political convictions and adventurous spirit. Like the journalist/writer Connor and the musician Octave, Gregory could symbolize a desire that transgresses the social order. Yet this would be a misreading. Nothing in the show suggests that Elizabeth seriously considers leaving her "husband" Philip or that Gregory is the reason they split up. In order to understand the meaning of remarriage, we must know why Elizabeth and Philip split up in the first place. This will tell us how the characters had to change or what they had to accept in order to be able to live together.

According to Cavell, the reason for bringing film and philosophy together is that they enable a fuller understanding of moral perfectionism. He explains perfectionism as follows:

This is the aim of moral reasoning in perfectionism, not to assess pluses and minuses of advantage, nor to assess whether the act is 
recommendable universally, but yet to see to what those two standard theories wish to accomplish, namely that the one in question make himself intelligible, to others and to himself. ${ }^{1}$

Cavell points out that the challenge of moral life emerges not from of lack of moral knowledge or even the conflict between moral duties, but rather "from a confusion over your desires." In Season One of The Americans we see just such a confusion. In an early episode, Elizabeth betrays Philip. The betrayal is not her affair, which had been going on for years, but rather the moment when she denounces Philip to her superior at the KGB. She tells her handler that Philip might defect. Somewhat counterintuitively, I want to argue that this is the turning point in their relationship, the answer to the question why, after fifteen years of marriage, she allows herself to become romantically attached to Philip. This betrayal is an expression of Elizabeth's confusion over her desires. She has always been completely dedicated to the Soviet ideology and to her role in an organization that she believes to be advancing this ideology. Truthfully reporting her doubts about Philip's loyalty to the KGB seems as if it is obviously the right thing to do, but it ends up having the opposite effect. It makes her aware that in fact she feels greater or at least equal loyalty to Philip. This realization motivates her to try to build a stronger marriage with Philip.

Elizabeth discovers that intimacy, however, is also a source of vulnerability. Later in the season, Philip is told to go to New York, where he meets with Irina, a former girlfriend from the USSR, the woman that he had to leave behind in order to accept his professional role and go undercover as an American. He spends the night with Irina but rejects her suggestion that they defect together. Philip's sexual infidelity is not an issue. Both Elizabeth and Philip use sex instrumentally to pursue their assigned tasks, but this infidelity is motivated by desire not duty; moreover, he lies about the brief liaison and, when Elizabeth finds out about the deception, she tells him to move out.

Stanley Cavell, Cities of Words: Pedagogical Letters on a Register of the Moral Life (Cambridge, MA, and London: Belknap/Harvard University Press, 2004), p. 42.

2 Ibid. 
How does this compare with the tripartite structures of The Philadelphia Story and The Rules of the Game? I want to suggest it is a more subtle variant on the same theme. Elizabeth too is confronted with a choice between three options, the moral certainty of rigid ideology, the sense of control found in autonomy, and the heteronomy of love. When she tells Philip in Russian "come home" she acknowledges her own vulnerability and accepts the possibility of betrayal that comes with loving someone else. In an earlier episode, Nina, a low-level staffer at the Soviet Embassy, told Stan, "You Americans think everything is white and black. For us, everything is grey." In fact, Elizabeth did see things as either black or white, but grey begins to seep in.

The Americans is not a show that teaches moral lessons. It does not tell us to do our Kantian duty or to privilege the family over country, or the cause over self-interest. Instead, it vividly depicts what Cavell calls "the moment of encounter or challenge." 3 Part of the vividness comes from the spy scenario, but its emotional depth and insight comes from the way that it makes these moments resonate with the moral imperfectionism of everyday life. Love is about the possibility of being betrayed and the reality that you can betray someone and still love them. This runs counter not only to the Hallmark card sentimental version of love, but also to the capital "R" Romantic account of love as a source of clarity, identity and purpose. This is quite similar to the message that Cavell wants to draw from The Philadelphia Story. He insists that the ceremony that renews the bond between Dexter and Tracy is not portrayed as a resolution to the eros/nomos problem, but as an event that marks the protagonists' willingness to try to "be first-class human beings" while recognizing the difficulty of this task and the uncertainty of the result. Perhaps that was not the take-home point for the audience in the theater, but it seems to have been the intent of the director, who ended the film with the intrusive snapshot intended for Spy magazine, a sly reminder that everything does not conclude neatly.

3 Ibid, p. 43. 
One of the distinctive features of serialized television is that it is continuous rather than finite. The Americans does not end with Elizabeth's request "come home" and in the second season the audience gets to see that this moment, while transformative, does not solve everything. Remarriage is still marriage and marriage is work. Along with some moments of intimacy that are nourishing to both, there are terrible misunderstandings that reveal a gulf between husband and wife. For example, Philip is deeply shaken by some acts of violence that he commits. Elizabeth reminds him that they are at war and he replies in a tired voice, "You don't have to give me the speech. I know we are at war. But you just find it easier than I do." She turns to him and says, "You think I find it easy?" This is a powerful scene, because it reminds us how even the most intimate relationships rest on misrecognition. It also suggests that there can be a kind of emotional division of labor in relationships. When one partner expresses an emotion this may mean that the other is prohibited from doing so, because this reticence is the only way to preserve a balance that must be maintained. If Elizabeth expressed Philip's doubts, then it would no longer be possible to do their jobs and their family would fall apart. The show constantly insinuates that undercover agents are not the only ones who play roles. The rest of us may not wear such cool wigs, but the existence of masks is not exclusive to the world of espionage.

\section{II}

The Americans, which has just been renewed for a third season, demonstrates that "cinema" can be commercially successful and still provide a place for moral reflection. By bringing together thought and emotion and situating moral puzzles in a register that is both fantastic and yet familiar, it could plausibly fit into the category of "Emersonian perfectionism." ${ }^{\text {"4 }}$ We are asked to think about what it means to be a good 
person and we are constantly reminded to question our certainty that we know the answer to that question. The very premise of the show, which asks the audience to identify with KGB agents who kill innocent people, implies that it is not easy to distinguish the good guys from the bad.

The second part of this response considers some objections to the ideas presented in the first part. The first objection follows directly from the preceding claim. If the show fosters emotional identification with "the bad guys" doesn't this prove that Rousseau's concern is legitimate? The problem with poetry/drama (and by extension film and television) is that it incites intense emotions that hinder judgment rather than enhance it. According to Rousseau, Molière encourages his audience to laugh at the honest man and to identify with the knave. Rousseau's second point is that it is a mistake to pay exclusive attention to the content of spectacle and overlook the structure of reception. What was true of the theater is even more true of cinema and television. Even the most exciting and morally provocative television ensconces us in our dark basements and isolates us from fellow citizens, thereby weakening real solidarity. The next part of this response will respond to these two objections.

Does The Americans hinder our judgment by romanticizing the KGB and encouraging the audience to identify with brutal killers? Does it suggest a moral equivalence between the United States and the Soviet Union? In answering these questions there are a few things to consider. First, if it were a show aimed at a Russian audience, these might be more serious concerns. The show does point to a certain moral equivalence, and, while the USSR of Brezhnev was not the USSR of Stalin, the show may indeed fail to highlight the full extent of repression and material deprivation in Russia (but it certainly does acknowledge these facts). This story, viewed in Russia, might possibly contribute to a nationalist mythology by reinforcing an ideological picture of KGB agents as morally conflicted and well-meaning patriots trying to make the world a better place. In the United States, however, it does not have that ideological effect and the moral equivalence serves to cast doubt 
on a different ideological picture, that of the United States as a beacon of integrity and justice.

Another response to this line of criticism is that the show forces the audience to acknowledge and consider moral ambiguity and conflict rather than to simply identify with the protagonists. It does this in two ways. First, it does not sanitize its characters by ensuring that they never do anything that really violates conventional morality. In the first season, Elizabeth executes a source because the center is worried that he could betray the KGB; she kills someone who is on the same side, someone who risked his own career and life to help the cause. Throughout the show people who are not involved in geopolitics are killed or exposed to grave danger when it is necessary to attain political objectives. Elizabeth explicitly endorses the consequentialist logic of the ends justifying the means. By encouraging us to identify with Philip and Elizabeth while fully exposing their brutality, we are forced into the same dilemma the characters are confronting, the tension between affect and judgment.

The show is also structured around a parallel between the KGB and the FBI. A central character is Stan Beeman, an FBI agent and neighbor of the Jennings. He is a serious and dedicated professional who has sacrificed his family for his job; he no longer feels at home after spending several years undercover with a white supremacist organization. He is neither cruel nor corrupt, yet he murders a low-level Russian intelligence officer in retribution for his partner's death and begins an affair with one of his sources. The Americans is not merely a show that makes villains into heroes. Instead, it does something much more unusual. It humanizes the characters on both sides of the binary between good guys and bad guys, cops and robbers. While the characters are sometimes moralistic, insofar as they express moral certainty and rigidity, the structure of the show itself does just the opposite, it provides a context for reflecting on moralism. ${ }^{5}$

Wendy Brown, States of Injury: Power and Freedom in Late Modernity (Princeton, NJ: Princeton University Press, 1995). 
Even if my sympathetic account of the content is persuasive, this means little if the very position of the spectator is fundamentally harmful. There is a strong and a weak version of this argument. The weak version is that a spectacle is fine as entertainment, but problematic when political theorists place this form of enjoyment at the center of their understanding of politics. To put it crudely, the objection goes something like this. Meetings, leafleting and deliberating about policy are difficult or boring. Instead of trying to change wordly things in association with others, we want to believe that a subtle reading of our highbrow shows is an important contribution to democratic politics. The stronger version of the argument, introduced by Rousseau and tentatively endorsed by Dienstag, is that going to the movies is like sojourning in the land of the lotus-eaters: "we are apt to let it take the place of those more truly democratic experiences, until the day arrives when we have lost our ability to tell the difference or, worse, when we prefer the dream, which we think we control, to the waking life, which we know we do not."

This is related to the argument made by Joseph Heath and Andrew Potter in their book The Rebel Sell. ${ }^{6}$ The Rebel Sell mercilessly mocks the pretentions of academics and hipsters who cling to the conceit that their lifestyle choices and aesthetic preferences constitute meaningful political action. They remind us that buying an ironic T-shirt does not weaken the dominant discourse and that raising backyard chickens is not a decisive blow against capitalism. The regime of the sensible is not reconfigured by our art installations or facial hair. Heath and Potter's point is not just that these lifestyle choices are consumerist in their own niche way, but rather that they are a classic form of mystification. Critical consumerism takes dissent and channels it away from practical and effective political activity toward narcissistic expressions of personality. Not only do the aesthetics of the self come to replace political mobilization, but they also make it difficult to recognize that this

6 Joseph Heath and Andrew Potter, The Rebel Sell: Why the Culture Can't Be Jammed (Toronto, ON: Harper Perennial, 2005). 
substitution has taken place. For Heath and Potter, the political goals of the left - fulfilling basic material needs, dismantling social hierarchies, and making space for individual freedom - are advanced through community organization and political participation.

The Rebel Sell is not focused primarily on cinema, but cinema could be an example of this broader tendency. Dienstag makes a similar point at the end of his essay. Following Rousseau, he argues that we should spend more time engaging in political activity and less time hypnotized by representations of the actions of others. There is empirical evidence for the claim that these activities are indeed mutually exclusive. In Bowling Alone, Robert Putnam suggests that up to 40 percent of the decline in associational activity may be due to the increased time spent watching television. ${ }^{7}$ Theorists who are more sympathetic to the view that cultural criticism is a key dimension of political activity argue that aesthetics can foster a democratic ethos. But, as Ella Myers points out in her book Wordly Ethics, ${ }^{8}$ the connection between democratic ethos and political action is seldom spelled out. Even if we sympathize with others, this does not mean that we are willing to act on their behalf or that we are capable of acting in ways that foster equality rather than noblesse oblige or of creating political associations.

Before assessing this line of criticism, we need to disentangle different parts of the argument. To do so, I turn back to Rousseau in order to understand his objection to the theater and how his argument might illuminate the contemporary debate. For Rousseau, the theater is a paradigmatic example of a certain type of collective experience, one that functions as a substitute for authentic public life. It simulates something that reassembles public life by bringing strangers into contact with one another, but, according to Rousseau, this commonality is based on an illusion. An emotional feeling of togetherness hides the lack of any real interaction that could overcome the isolation of modern, urban life.

Robert D. Putnam, Bowling Alone: The Collapse and Revival of American Community (New York: Simon \& Schuster, 2000).

8 Ella Myers, Worldly Ethics: Democratic Politics and Care for the World (Durham, NC, and London: Duke University Press, 2013). 
Rousseau also points out that the commercial nature of the theater exacerbates inequalities and encourages invidious comparisons. He contrasts commercial theater with public festivals that bring people together as equals and citizens. ${ }^{9}$

At first, Rousseau's Letter to M. d'Alembert appears to be a polemic against the theater, very much indebted to Plato's argument in The Republic. Like Plato, Rousseau worries that the theater appeals to the emotions rather than reason, and glorifies morally dubious modes of conduct. Rather than elevating, instructing, or challenging the spectator, the theater must appeal to the tastes of masses in order to maintain its commercial viability. Rousseau also stresses the negative consequences of the theater for Geneva, a city not yet corrupted by the habits of city life. Introducing the theater to Geneva would seduce citizens and draw them from more wholesome pursuits, thereby setting in motion a dynamic of consumerism and competition that would undermine the solidaristic basis of the republic. It is crucial to remember that he emphasized that theater functions differently in different places. It might actually prevent the corrupt Parisians from engaging in even more decadent activities, but it would lead to Geneva's decline.

Rousseau makes four distinct arguments:

- Theater is a bad influence in places where people would otherwise engage in more worthwhile activities.

- It is a form of public life based on hierarchy, comparison, and vanity rather than solidarity and equality.

- The commercial nature of the theater makes it ill-suited to challenge conventional taste.

- The narrative/dramatic form appeals to emotion and may enervate reason.

In response to the first, I think it is clear that we are Parisians and not Genevans. There is no going back to the real or imagined time when we

Jean Starobinski, Jean-Jacques Rousseau: Transparency and Obstruction trans. Arthur Goldhammer (Chicago, IL: University of Chicago Press, 1988). 
spent our evenings in serious conversation, political action and musical performance. Were it not for the pleasure of spectatorship in the golden age of television, I probably would not be pursuing particularly decadent pleasures, but I might well be surfing the Internet in a state of semi-distraction.

Rousseau's second criticism, too, was aimed at a particular time and place. The social experience of the eighteenth century theater was highly stratified and the physical arrangement of space enabled a very public performance of status. The opposite is true of the modern cinema, which may not be democratic in the sense of encouraging public spiritedness or deliberation, but is egalitarian in pricing and access. Viewing television, of course, is even less an expression of vanity and status. Some people may view their shows on a gigantic high-tech television, but the television is located in a private space and, therefore, it is not primarily a form of conspicuous consumption.

The third and fourth points have already been addressed above. Commercial entertainments do have to find a way to balance mass appeal with aesthetic innovation and critical perspectives. Sometimes this entails a hint of doubt after the happy ending, as in The Philadelphia Story. In "Golden Age" television shows such as The Sopranos, Breaking $\mathrm{Bad}$, and The Wire, this involves taking popular genres - the Mafia, cops and robbers - and rewriting them with protagonists who are not stock characters, and introducing visual and sound effects that open up new perspectives and scenarios that cast doubt on dominant ideology. They are able to do so in part because technological changes have made it easier to make money on shows that do not attract a mass audience.

Cable television has made it possible to produce shows that appeal to a smaller but committed audience, bypassing the mass audience necessary to attract national advertisers. Streaming makes it even easier to match individual tastes with specific content. In the eighteenth century, if a play did not appeal to a wide cross-section of the local population, the actors would perform to an empty theater and ticket sales would not cover their salaries. The age of mechanical reproduction allows for more specialization, but cinemas still need a large number of people to 
come to the same place at the same time. This requires costly infrastructure, which in turn requires marketing budgets to attract audiences. Internet-based television makes it possible to attract a geographically dispersed audience and to do so in a more gradual fashion. Rather than inundating people with costly advertising, it is possible to wait until reviews, word of mouth and commentary draw interested viewers who can catch up on older episodes by downloading them. These technological conditions make it possible, in a way that perhaps was not in Rousseau's day, to create spectacles that do challenge conventional wisdom and critique dominant ideology.

Dienstag does not write about television, but his comments imply that he thinks that it exacerbates the problems associated with cinema. Since television is viewed in private, it is even more isolating and individualizing than cinema. It has none of the aura of a spectacle, but all of the disadvantages: representation, commodification and passivity. I am not so sure. Spectatorship is not necessarily passive. Often a text - a film, television show, play, or novel - poses a puzzle rather than preaching a sermon. It invites the viewer to take part in a process of decoding and interpretation. Rousseau worried that the theater might turn us all into actors, people who are comfortable with dissimulation and masks. I am hopeful that the Golden Age of Television may turn us all into critics, taking the skills that we use to decipher television shows and use them to interpret our own lives. I have learned about marriage through viewing The Americans. Television shows can also serve as a kind of social glue. The experience of viewing may be isolating, but the task of interpretation can be collective. Popular niche television shows provide something to talk about other than real-estate prices, work and schools. Outside of a book club or university seminar, it is unusual to read a book together with other people at the same time, but movies and television shows are still events that create the possibility of a shared experience of interpretation.

The logics of spectatorship and quest are not necessarily opposed, but nor are they necessarily interrelated. Like Machiavelli donning his ancient robes, we sometimes read texts (including cinematic ones) and 
try to enact the insights that we draw from them. Other times, however, cinema is a form of escape, a reproduction of ideology, or an exercise in nostalgia. Notwithstanding the specific objections presented in this response, I think that Dienstag's motivating concern is valid. He is right to worry that the quest of political action - the struggle to improve the world - is more challenging and more important than watching a movie or an innovative and insightful show on television. It is not enough to see things through a slightly different lens. We must also create a different world. 